\title{
METTL3 Inhibitors for Epitranscriptomic Modulation of Cellular Processes
}

\author{
Elena V. Moroz-Omori ${ }^{+},{ }^{[a]}$ Danzhi Huang ${ }^{+}{ }^{[a]}$ Rajiv Kumar Bedi, ${ }^{[a]}$ Sherry J. Cheriyamkunnel, ${ }^{[a]}$ \\ Elena Bochenkova, ${ }^{\text {[a] }}$ Aymeric Dolbois, ${ }^{\left[{ }^{[a]}\right.}$ Maciej D. Rzeczkowski, ${ }^{\text {[a] }}$ Yaozong Li, ${ }^{\text {[a] }}$ \\ Lars Wiedmer, ${ }^{\text {[a] }}$ and Amedeo Caflisch ${ }^{*[a]}$
}

The methylase METTL3 is the writer enzyme of the $\mathrm{N}^{6}$-methyladenosine $\left(\mathrm{m}^{6} \mathrm{~A}\right)$ modification of RNA. Using a structure-based drug discovery approach, we identified a METTL3 inhibitor with potency in a biochemical assay of $280 \mathrm{nM}$, while its enantiomer is 100 times less active. We observed a dose-dependent reduction in the $\mathrm{m}^{6} \mathrm{~A}$ methylation

\section{Introduction}

The finely organized network of gene expression comprising RNA transcription, splicing, transport, translation, and degradation is often perturbed in cancer. ${ }^{[1,2]}$ In addition to previously known regulators of gene expression, such as epigenetic modifications or miRNAs, the recently discovered layer of regulation based on co- and post-transcriptional RNA modifications gave rise to a new field named epitranscriptomics. ${ }^{[2,3]}$ While over 160 different RNA modifications have been discovered to date, one of the most abundant modifications, $\mathrm{N}^{6}$ methyladenosine or $\mathrm{m}^{6} \mathrm{~A}$ (comprising $0.1-0.4 \%$ of all adenosine in $\mathrm{mRNA}$ ), is involved in most of the aspects of RNA regulation, i.e., alternative polyadenylation, splicing (controls about $3 \%$ of alternatively spliced exons $\left.{ }^{[4]}\right)$, nuclear export, stability, and translation initiation. ${ }^{[2,3]}$ It is also found in other RNA species, including IncRNAs, ${ }^{[5]} \mathrm{rRNAs}^{[6]}$ and snRNAs. ${ }^{[7]}$ Dysregulated $\mathrm{m}^{6} \mathrm{~A}$ deposition is directly involved in the development of acute myeloid leukemia (AML) and lymphomas, difficult-to-treat blood cancers, ${ }^{[1,8-12]}$ as well being associated with other types of cancer (e.g., bladder, lung, ovarian, colorectal, bone, liver, gastric). ${ }^{[13-21]}$

In mRNAs and IncRNAs, most of the $\mathrm{m}^{6} \mathrm{~A}$ modifications are installed in $[G / A / U][G>A] m^{6} A C[U>A>C]$ consensus sites

[a] Dr. E. V. Moroz-Omori, ${ }^{+}$Dr. D. Huang, ${ }^{+}$R. Kumar Bedi, S. J. Cheriyamkunnel, E. Bochenkova, Dr. A. Dolbois, M. D. Rzeczkowski, Dr. Y. Li, Dr. L. Wiedmer, Prof. A. Caflisch

Department of Biochemistry, University of Zurich

Winterthurerstrasse 190, 8057 Zurich (Switzerland)

E-mail: caflisch@bioc.uzh.ch elena.omori@uzh.ch

$\left.{ }^{+}\right]$These authors contributed equally to this work.

Supporting information for this article is available on the WWW under https://doi.org/10.1002/cmdc.202100291

Special
issue
"C

This article belongs to the joint Special Collection with ChemBioChem, "Chemical Epigenetics".

C (c) 2021 The Authors. ChemMedChem published by Wiley-VCH GmbH. This is an open access article under the terms of the Creative Commons Attribution Non-Commercial NoDerivs License, which permits use and distribution in any medium, provided the original work is properly cited, the use is noncommercial and no modifications or adaptations are made. level of mRNA in several cell lines treated with the inhibito already after $16 \mathrm{~h}$ of treatment, which lasted for at least 6 days. Importantly, the prolonged incubation (up to 6 days) with the METTL3 inhibitor did not alter levels of other RNA modifications (i.e., $m^{1} A, m^{6} A_{m}, m^{7} G$ ), suggesting selectivity of the developed compound towards other RNA methyltransferases.

$\left(\mathrm{GGm}^{6} \mathrm{ACU} \text { is the most prevalent }\right)^{[22]}$ by the so-called m6AMETTL complex (MAC), consisting of methyltransferase-like protein 3 (METTL3) and METTL14. ${ }^{[3]}$ MAC is assisted by a regulatory complex (named MACOM, $\mathrm{m}^{6} \mathrm{~A}$ - METTL-associated complex) composed of WTAP, RBM15/B, VIRMA, ZC3H13 and HAKAl. ${ }^{[23]}$ The crystal structure of the METTL3/14 complex was resolved in 2016, ${ }^{[24-26]}$ revealing the function of each component. While METTL14 plays a scaffolding role in substrate RNA recognition, forming an RNA-binding groove at the interface of the two subunits, METTL3 carries out the catalytic transfer of the methyl group from a cofactor $S$-(5'-adenosyl)-L-methionine (SAM) onto the $\mathrm{N}^{6}$ atom of the adenine. ${ }^{[24-26]}$

To date, there are no cell-permeable inhibitors of METTL3/ 14 with a disclosed chemical structure except for the universal nucleoside analogue sinefungin, which inhibits most methyltransferases and is not selective for METTL3. ${ }^{[27,28]}$ Therefore, all published studies of the role of $\mathrm{m}^{6} \mathrm{~A}$ in cancer have relied on the knockdown/overexpression of the writers, erasers, and readers. In contrast to this approach, using small-molecule inhibitors preserves the function of the target enzyme to act as a scaffold for protein-protein interactions that would otherwise be disrupted by RNAi, thus enabling discrimination between the enzymatic and structural roles. Indeed, it has been demonstrated that both a catalytically active and a nonfunctional METTL3 lead to a reduction in p-AKT levels highlighting the $\mathrm{m}^{6} \mathrm{~A}$-independent function of METTL3. ${ }^{[10]}$ In addition, small-molecule inhibitors enable titration experiments across a range of concentrations to be performed, ranging from mild perturbation to near-complete inhibition of the METTL3 enzymatic activity, which can reveal a spectrum of phenotypes. Generally, inhibitors can inactivate their targets rapidly, allowing precise temporal control over METTL3 function. This is particularly important for studying downstream effects of $m^{6} \mathrm{~A}$ depletion on gene and protein expression and will help to elucidate the $\mathrm{m}^{6} \mathrm{~A}$ regulatory network in health and disease.

Here we report a nanomolar inhibitor of METTL3 (UZH1a) which is selective and cell-permeable, while its enantiomer UZH1b is essentially inactive. The crystal structure of the 
complex shows several favourable interactions of the UZH1a chemical probe with METTL3, some of which are not observed in the METTL3/SAM complex and thus provide selectivity against other SAM-dependent methyltransferases. Furthermore, the characterization of UZH1a in biochemical and cellular assays provides evidence that UZH1a has a good potential for the development of a lead compound against METTL3-dependent cancers.

\section{Results and Discussion}

Our initial efforts to develop a potent and selective METTL3 inhibitor were focused on screening an adenine-based library, which yielded several hits with micromolar potency in a homogenous time-resolved fluorescence (HTRF) enzyme inhibition assay. ${ }^{[29]}$ Protein structure-based optimization coupled with compound potency evaluation in our HTRF assay ${ }^{[30]}$ resulted in the high-nanomolar inhibitor UZH1a (Figure 1a). The potency of UZH1a in the HTRF assay was $280 \mathrm{nM}$, while its enantiomer UZH1b was 100-fold less active (Figure 1b). We confirmed the binding of UZH1a but not its enantiomer UZH1b to METTL3 by X-ray crystallography (Figure 1c). The UZH1a inhibitor fills the pocket of the adenosine moiety of SAM but not the pocket of the SAM methionine. Besides the favourable van der Waals contacts, there are several hydrogen bonds between polar groups of the UZH1a inhibitor and METTL3 (yellow dashed lines in Figure 1c). The pyrimidine moiety is engaged in two hydrogen bonds with the backbone $\mathrm{NH}$ groups of Ile378 and Asn549. It is also involved in an edge-to-face $\pi$ stacking arrangement with the phenol of Phe534 and $\pi$ interactions with the amide group of the Asn549 side chain. The hydroxyl group is involved as the donor in a hydrogen bond with the side chain oxygen atom of Asn549 (distance of $2.5 \AA$ ) and in water-bridged polar interactions (distance of $2.8 \AA$ ) with the backbone $\mathrm{NH}$ and $\mathrm{CO}$ groups of residues 550 and 535 , respectively. There is also an intra-inhibitor hydrogen bond between the amide $\mathrm{NH}$ and phenolic oxygen of UZH1a (green dashed line in Figure 1c). Notably, the binding of UZH1a results in a conformational rearrangement ( $6 \AA$ displacement of the amino group) of the Lys513 side chain with respect to the Lys513 orientation in the complex of METTL3 with SAM or sinefungin (Figure $1 \mathrm{~d}, \mathrm{PDB}$ code $6 \mathrm{Y} 4 \mathrm{G}$ ). In detail, the tertiary amino group of UZH1a replaces the primary amine of Lys513 in the salt bridge with Asp395. As a consequence, the amine of Lys513 replaces the amino group of SAM in the salt bridge with Glu532. These castling-like changes of ligand/METTL3 and intraMETTL3 ionic interactions are likely to provide selectivity against other SAM-dependent methyltransferases. Indeed, UZH1a demonstrated high selectivity towards other protein methyltransferases (as well as several promiscuous protein kinases), with remaining enzymatic activity of over $75 \%$ at $10 \mu \mathrm{M}$ concentration of UZH1a (Table 1).

UZH1a possesses favourable physicochemical properties and is therefore compatible with cell-based experiments. Indeed, its molecular weight is relatively low $(558 \mathrm{~g} / \mathrm{mol})$, and the octanol-water partition coefficient $\log \mathrm{D}_{7.4}$ of 2.6 is optimal for
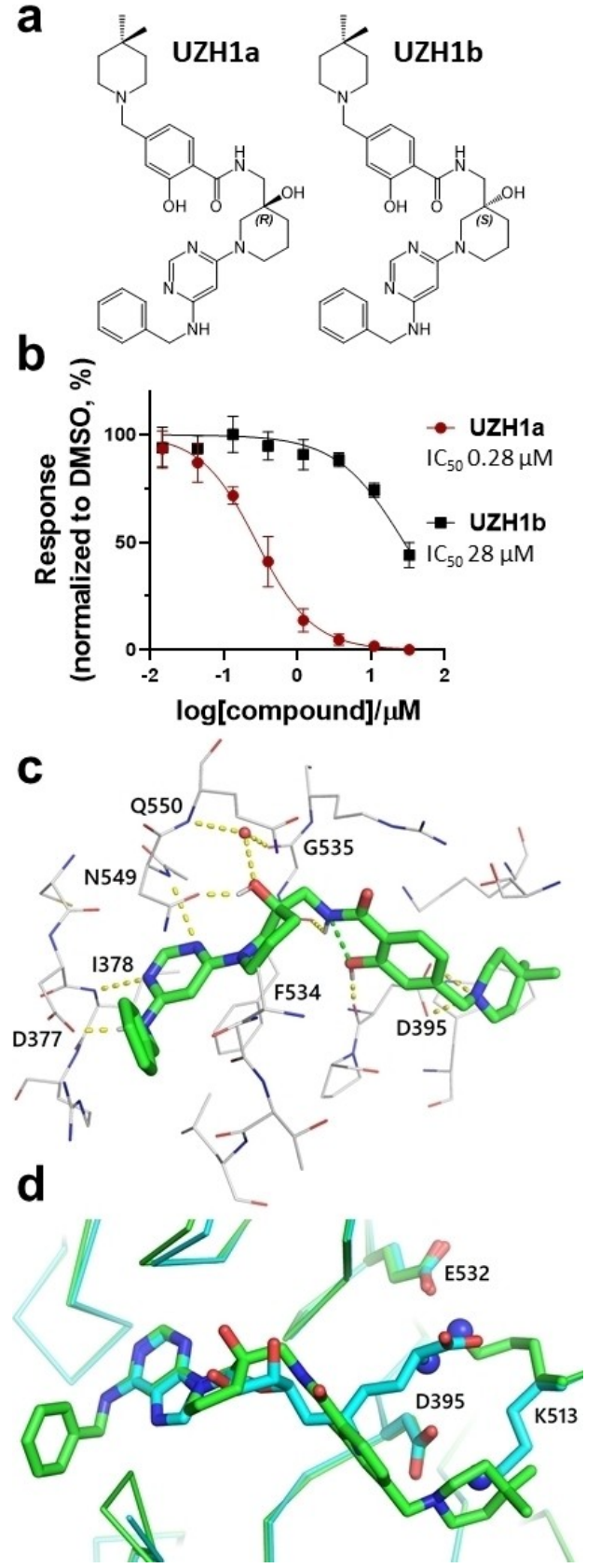

Figure 1. In vitro characterization of METTL3 inhibitors. (a) Chemical structures of $\mathrm{UZH} 1 \mathrm{a}$ and $\mathrm{UZH} 1 \mathbf{b}$; absolute configuration was determined by X-ray crystallography. (b) Enzymatic activity assay based on HTRF, mean $\pm S D, N=4$. (c) Crystal structure of METTL3/14 in complex with UZH1a (carbon atoms in green, PDB code 7ACD). Hydrogen bonds (yellow and green dashed lines) and a water molecule in contact with the inhibitor (red sphere) are shown. (d) Overlay of crystal structures of METTL3/14 in complex with UZH1a (carbon atoms in green) and METTL3/14 in complex with sinefungin (carbon atoms in cyan, PDB code 6Y4G). The amino groups involved in the castling-like conformational change are highlighted (blue spheres on $\mathrm{N}$ atoms).

cell uptake. UZH1a was highly permeable $\left(P_{\text {app }}>1 \cdot 10^{-5} \mathrm{~cm} / \mathrm{s}\right)$ in a Caco-2 permeability assay used to evaluate intestinal uptake (Table 2). However, the efflux ratio of 2.3 suggests that UZH1a may be subject to active efflux. Importantly, the large difference in biochemical potency of UZH1a and UZH1b (>100-fold, 


\begin{tabular}{|c|c|c|c|c|c|}
\hline \multirow[t]{2}{*}{ Type } & \multirow[t]{2}{*}{ Protein } & \multicolumn{2}{|c|}{ Remaining activity $[\%]^{[a]}$} & \multirow[t]{2}{*}{ Control IC $50[\mu \mathrm{M}]$} & \multirow[t]{2}{*}{ Control compound ${ }^{[b]}$} \\
\hline & & Replicate 1 & Replicate 2 & & \\
\hline \multirow[t]{7}{*}{ methyltransferase } & DOT1L & 100 & 98 & 0.278 & $\mathrm{SAH}$ \\
\hline & G9a & 96 & 99 & 1.95 & $\mathrm{SAH}$ \\
\hline & MLL4 complex & 88 & 89 & 2.11 & $\mathrm{SAH}$ \\
\hline & PRDM9 & 101 & 101 & 3.98 & chaetocin \\
\hline & PRMT1 & 91 & 88 & 0.140 & $\mathrm{SAH}$ \\
\hline & SETD2 & 99 & 103 & 7.39 & $\mathrm{SAH}$ \\
\hline & SMYD3 & 88 & 92 & 18.7 & $\mathrm{SAH}$ \\
\hline \multirow[t]{10}{*}{ kinase } & Abl & 80 & 74 & - & - \\
\hline & CDK2/cyclinA & 83 & 72 & - & - \\
\hline & cKit & 95 & 101 & - & - \\
\hline & DDR1 & 96 & 85 & - & - \\
\hline & Flt3(D835Y) & 80 & 68 & - & - \\
\hline & Fms & 92 & 102 & - & - \\
\hline & JAK1 & 101 & 102 & - & - \\
\hline & PDGFR $\alpha$ & 88 & 81 & - & - \\
\hline & Pim-1 & 100 & 95 & - & - \\
\hline & ROCK-I & 86 & 80 & - & - \\
\hline
\end{tabular}

[a] The remaining activity is the percentage of enzymatic activity in the presence of $10 \mu \mathrm{M}$ UZH1a with respect to the buffer solution containing DMSO. The closer to $100 \%$ are these values, the weaker the inhibitory potency of UZH1a. [b] SAH = S-(5'-adenosyl)-L-homocysteine.

\begin{tabular}{|c|c|c|c|c|}
\hline \multirow[t]{2}{*}{ Compound } & \multirow[t]{2}{*}{ Direction } & \multicolumn{2}{|c|}{$P_{\text {app }}\left[10^{-6} \mathrm{~cm} / \mathrm{s}\right]$} & \multirow[t]{2}{*}{$\mathrm{P}_{\mathrm{app}}(\mathrm{B}-\mathrm{A}) / \mathrm{P}_{\mathrm{app}}(\mathrm{A}-\mathrm{B})$} \\
\hline & & Replicate 1 & Replicate 2 & \\
\hline \multirow[t]{2}{*}{ Metoprolol } & $A-B$ & 33.7 & 31.4 & \multirow[t]{2}{*}{1.1} \\
\hline & B-A & 34.7 & 33.3 & \\
\hline \multirow[t]{2}{*}{ Atenolol } & $A-B$ & 0.5 & 0.4 & \multirow[t]{2}{*}{2.0} \\
\hline & B-A & 0.9 & 1.0 & \\
\hline \multirow[t]{2}{*}{ Erythromycin } & $A-B$ & 0.3 & 0.2 & \multirow[t]{2}{*}{62.9} \\
\hline & $B-A$ & 18.1 & 17.5 & \\
\hline \multirow[t]{2}{*}{ UZH1a } & $A-B$ & 12.4 & 11.8 & \multirow[t]{2}{*}{2.3} \\
\hline & B-A & 25.6 & 28.8 & \\
\hline
\end{tabular}

$\mathrm{P}_{\mathrm{app}}$-apparent permeability coefficient, A-apical, B-basal.

Figure 1b) allows for discrimination of non-specific effects due to the chemical properties of the compounds and makes them highly suitable for mechanistic cellular studies.

Higher potency of UZH1a in comparison to UZH1b in the biochemical assay (Figure 1b) is consistent with higher thermal stabilization of the METTL3/14 construct by UZH1a than UZH1b in a protein thermal shift assay (Figure $2 \mathrm{a}, \Delta \mathrm{T}_{\mathrm{m}}=2.5^{\circ} \mathrm{C}$ and $0.5^{\circ} \mathrm{C}$ at $10 \mu \mathrm{M}$, respectively). This increased stabilization towards thermal denaturation allowed us to study UZH1a binding to its protein target directly in cells. HEK293T cells were transiently transfected with a plasmid encoding METTL3 catalytic domain (residues 356-580) tagged on its $\mathrm{N}$-terminus with ProLabel $^{\circledast}$ (ePL) peptide (42 aa) to investigate the UZH1a and UZH1b binding in a cellular thermal shift assay based on the InCell Pulse platform (Figure 2b). We observed increased fusion protein abundance at $46^{\circ} \mathrm{C}$ upon incubation with UZH1a, but not with UZH1b, with $\mathrm{EC}_{50}$ of $4 \mu \mathrm{M}$.

In line with the biochemical and cellular target engagement assays, we observed a dose-dependent reduction in $\mathrm{m}^{6} \mathrm{~A}$ methylation level in mRNA from the human leukemia cell line MOLM-13 treated with UZH1a $\left(\mathrm{IC}_{50}\right.$ of $\left.7 \mu \mathrm{M}\right)$, while UZH1b was less active at concentrations up to $100 \mu \mathrm{M}$ in these cells, as determined by triple-quadrupole LC mass spectrometry (Fig- ure 3a). However, the effect of the $\mathrm{m}^{6} \mathrm{~A}$ level depletion upon UZH1a treatment was attenuated by at least one order of magnitude in cells in comparison to the biochemical assay. This could be the consequence of cellular efflux (Table 2) or competition with high intracellular SAM/SAH levels. Interestingly, $\mathrm{m}^{6} \mathrm{~A}$ level reduction in $\mathrm{mRNAs}$ followed a first-order kinetics, with a maximum $\mathrm{m}^{6} \mathrm{~A}$ inhibition level of $70 \%$ and a half-decay time $\tau$ of $1.8 \mathrm{~h}$ (Figure $3 \mathrm{~b}$ ).

The latter value is lower than the average mRNA half-life in cells $(\approx 10 \mathrm{~h})^{[31]}$ and is in line with the previously observed rapid degradation of $\mathrm{m}^{6} \mathrm{~A}$-modified mRNAs. ${ }^{[4,32,33]}$ We have verified that $\mathrm{m}^{6} \mathrm{~A}$ level reduction was not caused by a reduction in METTL3 protein level (Figure 3c,d). Using UZH1a, we could, for the first time, directly estimate the average half-life of $\mathrm{m}^{6} \mathrm{~A}$ modified RNA in the cells. This result illustrates an important advantage of chemical inhibition of METTL3 over genetic manipulation, as it allows precise temporal control over METTL3 function due to the rapid cellular penetration of small-molecule probes. One has to bear in mind that this method does not allow the decay of $\mathrm{m}^{6} \mathrm{~A}$-modified $\mathrm{mRNA}$ to be distinguished from the potential demethylation of the transcripts via cellular ALKBH5. The latter, however, has been shown to affect only a small percentage of mRNAs after transcription. ${ }^{[4]}$

We confirmed that UZH1a was able to reduce $\mathrm{m}^{6} \mathrm{~A} / \mathrm{A}$ levels in mRNA fraction not only in the leukemia cell line MOLM-13 but also in at least two other cell lines (i. e., osteosarcoma U2OS cells and immortalized human embryonic kidney cell line HEK293T, Figure 4a). However, the $\mathrm{m}^{6} \mathrm{~A}$ level reduction $\mathrm{IC}_{50}$ values were slightly higher in these cell lines in comparison to MOLM-13 cells ( 9 and $15 \mu \mathrm{M}$ vs. $7 \mu \mathrm{M}$, respectively). Importantly, the ability to inhibit cellular $\mathrm{m}^{6} \mathrm{~A}$ levels in mRNA fraction was preserved for at least 6 days (Figure $4 b$ ).

Interestingly, siRNA-mediated METTL3 knockdown in both HEK293T and U2OS failed to adequately reduce $\mathrm{m}^{6} \mathrm{~A}$ levels in mRNA despite the strong reduction of METTL3 protein level (over $80 \%$, Figure 4c, d). It has previously been observed that 
a
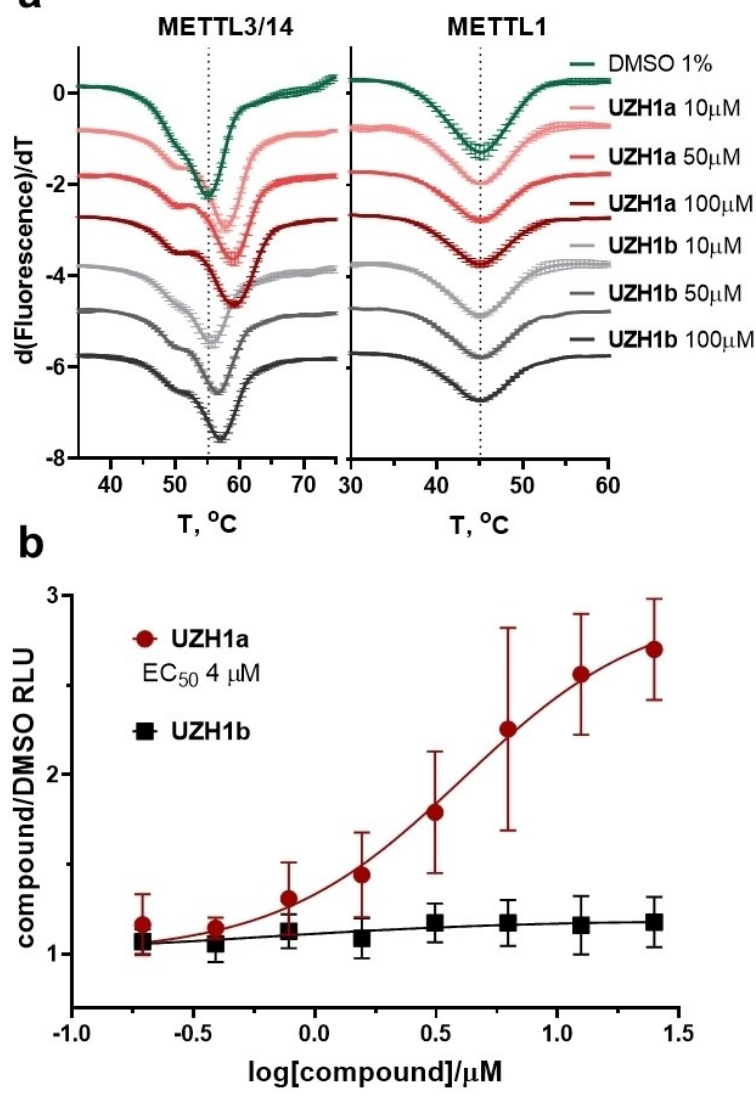

Figure 2. Protein thermal shift assay for METTL3/14 and METTL1 and cellular target engagement assay of UZH1a and UZH1b in HEK293T cells. (a) Results of the differential scanning fluorimetry (protein thermal shift assay) for METTL3/14 and METTL1 constructs. Derivative plot of the thermal denaturation curves of METTL3/14 and METTL1 in the presence of UZH1a (red), UZH1b (gray), or DMSO (green). Protein concentrations were $2 \mu \mathrm{M}$, mean $\pm S D, N=3$ (technical replicates). (b) Results of InCELL Pulse assay in HEK293T cells transfected with METTL3 construct and incubated with increasing concentrations of UZH1a and UZH1b for $1 \mathrm{~h}$ at $37^{\circ} \mathrm{C}$, followed by heating at $46^{\circ} \mathrm{C}$ for $3 \mathrm{~min}$. The soluble METTL3 fraction was quantified in luminescence-based assay, DMSO-treated cells served as normalization control, mean $\pm \mathrm{SD}, \mathrm{N}=3-4$ (biological replicates)

even a low residual level of METTL3 expression can maintain $\mathrm{m}^{6} \mathrm{~A} / \mathrm{A}$ ratio in cells. ${ }^{[34]}$ These findings illustrate yet another advantage of our inhibitor that is able to rapidly reduce $\mathrm{m}^{6} \mathrm{~A}$ levels up to $75 \%$ in a dose-dependent manner in a range of cell lines, and, therefore, comprises a valuable tool to probe various cellular functions of $\mathrm{m}^{6} \mathrm{~A}$-modified mRNAs.

In order to evaluate the selectivity of our METTL3 inhibitor towards other RNA methyltransferases in cells, we analysed the levels of $\mathrm{m}^{6} \mathrm{~A}$ as well as other RNA modifications (i.e., $\mathrm{m}^{6} \mathrm{~A}_{\mathrm{m}}$ $m^{1} A, m^{7} G$ ) in total RNA. It is known that $m^{6} A$ is present in other RNA species ${ }^{[6,7,35-37]}$ and is installed in rRNAs by enzymes other than METTL3 (i.e., METTL5/TRMT112 for $18 \mathrm{~S}$ and ZCCHC4 for $28 \mathrm{~S}$ ribosomal subunits, respectively). ${ }^{[35,36]}$ The average half-life of rRNAs and tRNAs, presenting the major RNA component in cells, is much longer than that of mRNA. ${ }^{[31,38]}$ Therefore, prolonged incubation times are necessary to evaluate potential non-specific inhibition of the methyltransferases modifying a

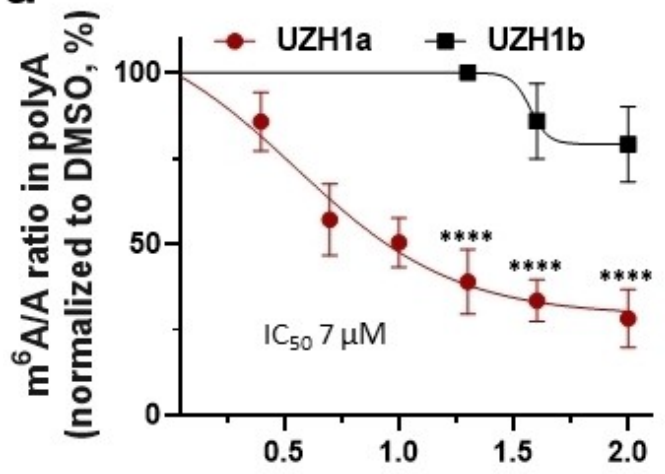

b

$\log [$ compound $] / \mu \mathrm{M}$
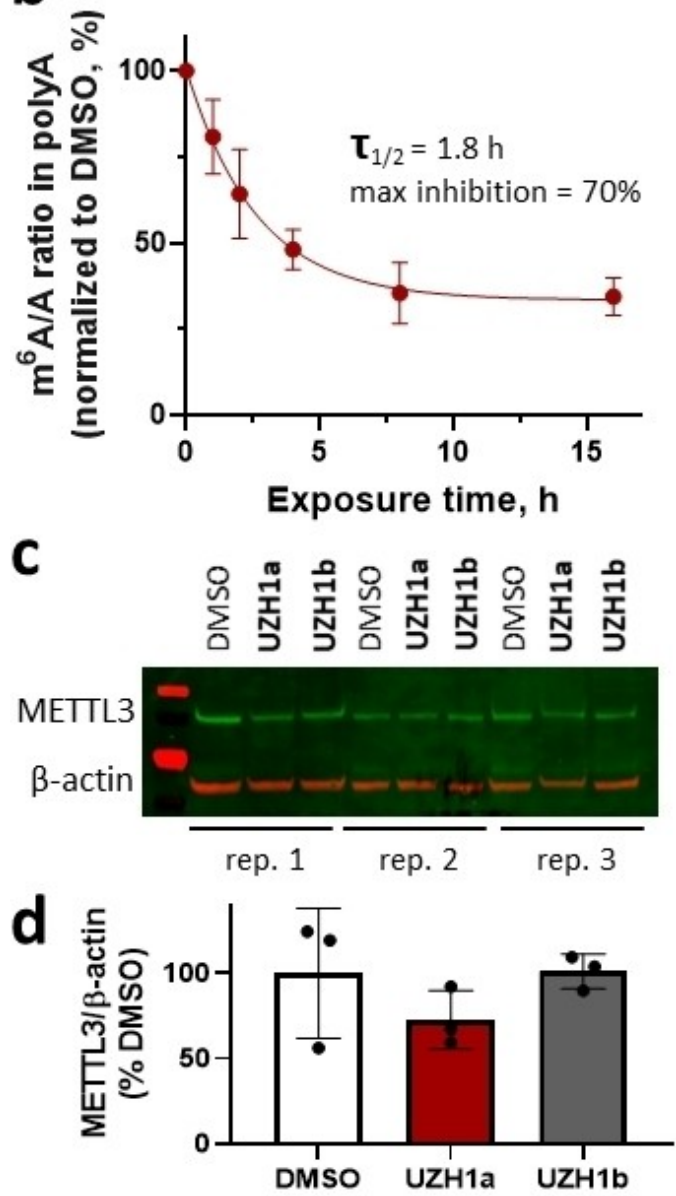

Figure 3. Cellular activity of the METTL3 inhibitor UZH1a in MOLM-13 cells. (a) Results of UPLC-MS/MS assay of $\mathrm{m}^{6} \mathrm{~A}$ level in mRNA from MOLM-13 cells upon UZH1a and UZH1b treatment at a dose range of 2.5 to $100 \mu \mathrm{M}$ for $16 \mathrm{~h}$, mean $\pm S D, N=3-7$ (biological replicates), ${ }^{* * * *} p<0.0001$ vs. UZH1b. (b) Kinetics of $\mathrm{m}^{6} \mathrm{~A}$ level reduction in mRNA from MOLM-13 cells upon UZH1a treatment at a dose of $40 \mu \mathrm{M}$ for 1 to $16 \mathrm{~h}$ determined in UPLC-MS/MS assay, mean $\pm S D, N=3$ (biological replicates), normalized to DMSO-treated samples for each time point. (c) Western blotting of METTL3 expression level in MOLM-13 cells after treatment with $40 \mu \mathrm{M}$ of UZH1a and UZH1b for $16 \mathrm{~h}$, $\mathrm{N}=3$ (biological replicates). (d) Quantification of the METTL3 signal intensity relative to $\beta$-actin in western blot images of compound treated versus DMSO only treated samples, mean $\pm S D, N=3$ (biological replicates). 
a

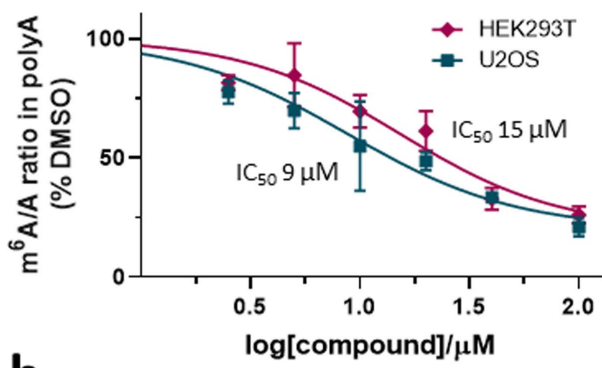

b

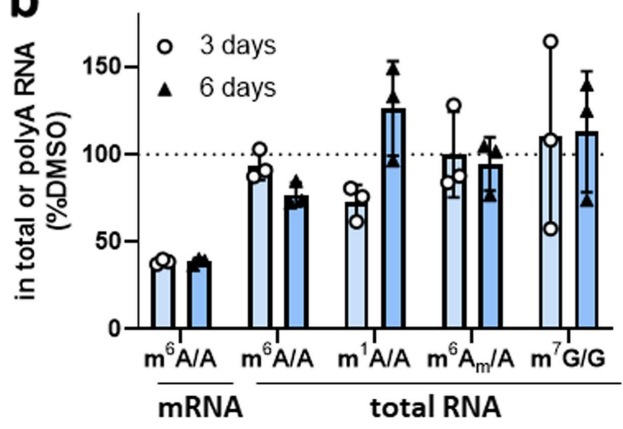

C

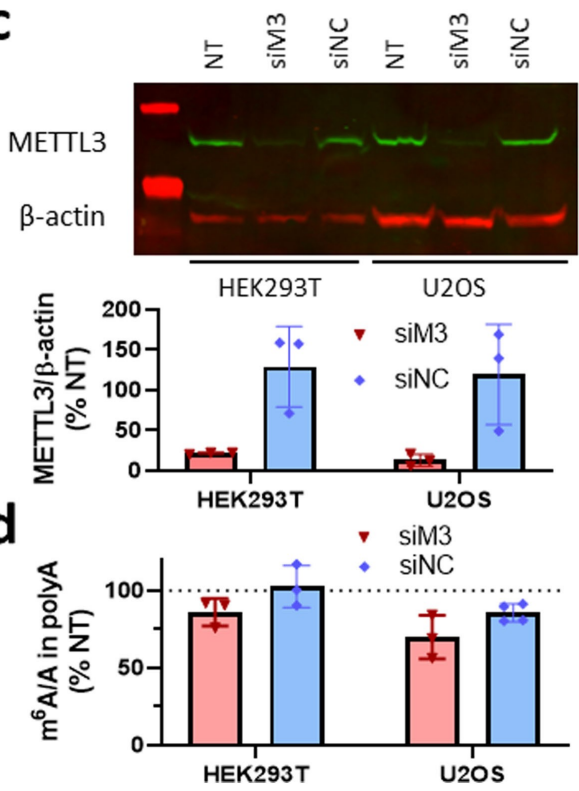

Figure 4. Cellular activity of the METTL3 inhibitor UZH1a and siRNAmediated METTL3 knockdown in HEK293T and U2OS cells. (a) Results of UPLC-MS/MS assay of $\mathrm{m}^{6} \mathrm{~A}$ level in mRNA from U2OS and HEK293T cells upon UZH1a treatment at a dose range of 2.5 to $100 \mu \mathrm{M}$ for $16 \mathrm{~h}$, mean $\pm S D, N=3$ (biological replicates), normalized to DMSO-treated samples for each cell line. (b) Results of UPLC-MS/MS assay of modified nucleosides level in mRNA fraction and in total RNA from U2OS cells upon $40 \mu \mathrm{M}$ UZH1a treatment for 3 and 6 days, mean $\pm S D, N=3$ (biological replicates), normalized to DMSO-treated samples. (c) Representative results of western blotting analysis of METTL3 protein level in HEK293T and U2OS cells after 72-h transfection with $50 \mathrm{nM}$ of siRNA targeting METTL3 (siM3), negative control siRNA (siNC), or in non-transfected cells (NT). Quantification of the METTL3 signal intensity relative to $\beta$-actin in western blot images of siRNA-treated versus non-transfected (NT) samples, mean $\pm S D, N=3$ (biological replicates). (d) Results of UPLC-MS/MS assay of $\mathrm{m}^{6} \mathrm{~A}$ level in mRNA from HEK293T and U2OS cells after 72-h transfection with $50 \mathrm{nM}$ of siRNA targeting METTL3 (siM3) or negative control siRNA (siNC), normalized to non-transfected cells (NT), mean $\pm S D, N=3-4$ (biological replicates). these RNA types. We studied the levels of $m^{6} A, m^{6} A_{m}, m^{1} A, m^{7} G$ in total RNA of U2OS cells treated with $40 \mu \mathrm{M}$ of UZH1a for 3 and 6 days and observed virtually no changes in these modifications (Figure 4b). In addition to the LC-MS/MS analysis of $\mathrm{m}^{7} \mathrm{G}$ methylation levels in total RNA after UZH1a treatment (Figure 4b), we used mechanistic protein thermal shift assay to confirm the absence of binding of our compound UZH1a to METTL1 (Figure 2a), an enzyme responsible for $\mathrm{m}^{7} \mathrm{G}$ installation on tRNA, ${ }^{[39,40]} \mathrm{mRNA}_{1}^{[41]}$ and miRNA. ${ }^{[42]}$ Overall, these results point out the exceptional selectivity of UZH1a towards other RNA methyltransferases.

\section{Conclusion}

Chemical probes that target proteins involved in the $\mathrm{m}^{6} \mathrm{~A}$ modification of RNA are essential for understanding the complexity of this epitranscriptomic regulatory network. Furthermore, they are also valuable starting points for designing novel drugs against several diseases ranging from cancer to viral infections. Here, we have characterized a small-molecule inhibitor of METTL3 by protein crystallography, a biochemical binding assay, and a battery of cellular assays. Our METTL3 inhibitor UZH1a shows high-nanomolar potency in the biochemical assay, good selectivity against a panel of protein methyltransferases and kinases, and is active in cells. Importantly, METTL3 chemical inhibition reduced the $\mathrm{m}^{6} \mathrm{~A} / \mathrm{A}$ ratio in mRNAs of three different cell lines (AML MOLM-13 cells, osteosarcoma U2OS cells, and the embryonic kidney cell line HEK293T). In addition, we confirmed the selectivity of our compound towards other RNA methyltransferases in a protein thermal shift assay as well as in living cells. The crystal structure of METTL3/14 in complex with UZH1a has revealed its binding mode and is used as the basis for the development of more potent inhibitors. Future work will focus on the implications of METTL3 inhibition in various disease models.

\section{Experimental Section}

\section{Compound characterization}

\section{UZH1a}

Purity $>95 \%$, confirmed by supercritical fluid chromatography (SFC).

${ }^{1} \mathrm{H}$ NMR $\left(500 \mathrm{MHz}, \mathrm{CD}_{3} \mathrm{OD}\right) \delta 7.95(\mathrm{~s}, 1 \mathrm{H}), 7.82(\mathrm{~d}, J=8.0 \mathrm{~Hz}, 1 \mathrm{H})$, $7.31-7.24(\mathrm{~m}, 4 \mathrm{H}), 7.23-7.18(\mathrm{~m}, 1 \mathrm{H}), 6.90(\mathrm{~s}, 1 \mathrm{H}), 6.86(\mathrm{~d}, J=8.0 \mathrm{~Hz}$, $1 \mathrm{H}), 5.58(\mathrm{~s}, 1 \mathrm{H}), 4.38(\mathrm{~s}, 2 \mathrm{H}), 3.64-3.37(\mathrm{~m}, 8 \mathrm{H}), 2.52(\mathrm{~s}, 4 \mathrm{H}), 1.84-$ $1.74(\mathrm{~m}, 2 \mathrm{H}), 1.72-1.59(\mathrm{~m}, 2 \mathrm{H}), 1.43(\mathrm{t}, J=5.6 \mathrm{~Hz}, 4 \mathrm{H}), 0.94(\mathrm{~s}, 6 \mathrm{H})$.

${ }^{13} \mathrm{C}$ NMR $\left(126 \mathrm{MHz}, \mathrm{CD}_{3} \mathrm{OD}\right) \delta 170.7,164.4,163.8,161.8,158.2$, $144.0,140.4,129.9,129.6,128.3,128.1,120.8,120.0,117.2,82.6$, $71.8,63.5,52.8,50.9,47.1,45.9,45.5,39.0,35.3,29.1,28.4,22.6$. Five carbon signals are missing due to overlapping of equivalent signals.

HRMS (ESI): m/z: calculated for $\mathrm{C}_{32} \mathrm{H}_{43} \mathrm{~N}_{6} \mathrm{O}_{3}{ }^{+}\left[\mathrm{M}+\mathrm{H}^{+}\right]$: 559.33912 found: 559.33851 


\section{$U Z H 1 b$}

Purity $>95 \%$, confirmed by SFC.

${ }^{1} \mathrm{H}$ NMR $\left(500 \mathrm{MHz}, \mathrm{CD}_{3} \mathrm{OD}\right) \delta 7.95(\mathrm{~s}, 1 \mathrm{H}), 7.83(\mathrm{~d}, J=8.0 \mathrm{~Hz}, 1 \mathrm{H})$, 7.31-7.24 (m, 4H), 7.23-7.18 (m, 1H), $6.91(\mathrm{~s}, 1 \mathrm{H}), 6.88(\mathrm{~d}, J=8.0 \mathrm{~Hz}$ $1 \mathrm{H}), 5.58(\mathrm{~s}, 1 \mathrm{H}), 4.38(\mathrm{~s}, 2 \mathrm{H}), 3.64-3.37(\mathrm{~m}, 8 \mathrm{H}), 2.54(\mathrm{~s}, 3 \mathrm{H}), 1.84$ $1.74(\mathrm{~m}, 2 \mathrm{H}), 1.72-1.59(\mathrm{~m}, 2 \mathrm{H}), 1.44(\mathrm{t}, J=5.6 \mathrm{~Hz}, 4 \mathrm{H}), 0.94(\mathrm{~s}, 6 \mathrm{H})$.

${ }^{13} \mathrm{C}$ NMR $\left(126 \mathrm{MHz}, \mathrm{CD}_{3} \mathrm{OD}\right) \delta 170.7,164.4,163.7,161.7,158.2$, $143.7,140.4,129.9,129.6,128.3,128.1,121.0,120.0,117.2,82.5$, $71.8,63.4,52.8,50.9,47.1,45.9,45.5,38.9,35.3,29.1,28.5,22.6$. Five carbon signals are missing due to overlapping of equivalent signals.

HRMS (ESI): m/z: calculated for $\mathrm{C}_{32} \mathrm{H}_{43} \mathrm{~N}_{6} \mathrm{O}_{3}{ }^{+}\left[\mathrm{M}+\mathrm{H}^{+}\right]$: 559.33912 found: 559.33848 .

IR ( $\mathrm{cm}^{-1}$, neat): $418,426,438,452,471,488,498,513,547,555,592$, $608,668,697,733,748,778,798,826,873,977,1027,1114,1150$, $1171,1226,1260,1306,1329,1362,1431,1453,1496,1505,1548$, $1595,2922,2948,3323$.

\section{Protein expression and purification}

Recombinant METTL3 ${ }_{354-580}$-METTL14 $4_{106-396}$ complex constructs for crystallization and for the use in enzymatic activity and protein thermal shift assays were expressed using the baculovirus/Sf9 insect cell expression system as previously described. ${ }^{[25]}$

The plasmid expressing the $\mathrm{N}$-terminally hexahistidine-tagged METTL1 protein was a gift from Cheryl Arrowsmith (Addgene ID: 25264). The protein was overexpressed for 12 hours at $20^{\circ} \mathrm{C}$ in Escherichia coli BL21 (DE3) cells upon induction with 0.2 mM IPTG. The cells were harvested and resuspended in the lysis buffer containing $100 \mathrm{mM}$ Tris- $\mathrm{HCl}$ at $\mathrm{pH} 8.0$ and $500 \mathrm{mM} \mathrm{NaCl}$. The cells were lysed by sonication and the cell lysate was clarified by centrifugation at $50^{\prime} 000 \mathrm{~g}$ for two hours and loaded onto Ni-NTA affinity column ( $5 \mathrm{~mL}$ HisTrap FF from GE Healthcare). After extensive washing with the wash buffer containing $100 \mathrm{mM}$ Tris$\mathrm{HCl}$ at $\mathrm{pH} 8.0,500 \mathrm{mM} \mathrm{NaCl}$ and $50 \mathrm{mM}$ imidazole the target protein was eluted with elution buffer containing $100 \mathrm{mM}$ Tris- $\mathrm{HCl}$ at $\mathrm{pH} 8.0,500 \mathrm{mM} \mathrm{NaCl}$ and $250 \mathrm{mM}$ imidazole. The $\mathrm{N}$-terminal hexahistidine-tag was removed by cleavage with tobacco etch virus (TEV) protease at 1:50 ratio. The excess imidazole was removed by overnight dialysis and the sample was subjected to secondary subtractive Ni-NTA affinity chromatography step to remove the protease and uncleaved protein. Finally, the protein was subjected to a gel filtration step using Superdex $7516 / 60$ column in a buffer containing $10 \mathrm{mM}$ Tris- $\mathrm{HCl}$ at pH 8, $150 \mathrm{mM} \mathrm{NaCl}$.

\section{Differential scanning fluorimetry (thermal shift assay)}

Thermal shift assay was performed as previously described with slight modifications. ${ }^{[43]}$ Briefly, protein (METTL1 or METTL3/14) at a final concentration of $2 \mu \mathrm{M}$ was mixed with UZH1a or UZH1b at final concentrations of $10,50,100 \mu \mathrm{M}$ in a final volume of $20 \mu \mathrm{L}$ in a buffer system consisting of $50 \mathrm{mM}$ HEPES at pH 7.5 and $150 \mathrm{mM}$ $\mathrm{NaCl}$. DMSO concentration was kept at $1 \%(\mathrm{v} / \mathrm{v})$. SYPRO Orange was added at a final dilution of $1: 1000(\mathrm{v} / \mathrm{v})$ as a fluorescence probe (ex/em 465/590 nm). Differential scanning fluorimetry was performed on a LightCycler ${ }^{\circledR} 480$ Instrument II (Roche Diagnostics, Indianapolis, IN). The temperature was raised with a step of $3.6^{\circ} \mathrm{C}$ per minute from $20^{\circ} \mathrm{C}$ to $85^{\circ} \mathrm{C}$ and fluorescence readings were taken at each interval. The reported values $\left(\Delta T_{m}\right)$ are calculated as the difference between the transition midpoints of an individual sample and the average of the reference wells (containing the protein and the DMSO only) in the same plate.

\section{Reader-based HTRF assay of METTL3 inhibition in vitro}

Compound potencies were evaluated by using a previously reported METTL3 inhibition assay. ${ }^{[30]}$ Briefly, the level of $\mathrm{m}^{6} \mathrm{~A}$ in the oligoribonucleotide substrate after the reaction catalyzed by METTL3-METTL14 was quantified by measuring specific binding of modified oligoribonucleotide to the $\mathrm{m}^{6} \mathrm{~A}$ reader $\mathrm{YTHDC1}_{345-509}$ by homogeneous time-resolved fluorescence (HTRF). Tested compounds that inhibit METTL3 decrease the $\mathrm{m}^{6} \mathrm{~A}$ level and, thus, reduce the HTRF signal. Response curves were plotted in GraphPad Prism 8.4 and fitted with nonlinear regression "log(inhibitor) vs. normalized response-variable slope", from which $\mathrm{IC}_{50}$ values were determined. The $I_{50}$ values are given as an average of at least three independent measurements for each compound.

\section{Protein crystallization}

The protein crystals of METTL3 ${ }_{354-580}$ METTL14 $4_{106-396}$ were obtained as previously described. ${ }^{[25]}$ Briefly, purified METTL3/14 complex was diluted to $5 \mathrm{mg} / \mathrm{mL}$ in $10 \mathrm{mM}$ Tris-Cl pH 8.0, $200 \mathrm{mM} \mathrm{NaCl}$. Crystals were obtained using the hanging drop vapor diffusion by mixing $1 \mathrm{~mL}$ complex solution with $1 \mathrm{~mL}$ reservoir solution containing $20 \%$ PEG3350 and $400 \mathrm{mM}$ of magnesium acetate. The soaking experiment was carried out by transferring crystals to a $1 \mu \mathrm{L}$ drop containing $100 \mathrm{mM}$ compound directly dissolved in the buffer containing $30 \%$ PEG3350, and $400 \mathrm{mM}$ magnesium acetate. After 16-h incubation at $22^{\circ} \mathrm{C}$, the crystals were harvested and flashfrozen in liquid nitrogen.

\section{Data collection and structure solution}

Diffraction data were collected at the PXIII beamline at the Swiss Light Source (SLS) of the Paul Scherrer Institute (PSI, Villigen, Switzerland) and processed using XDS as previously described. ${ }^{[29]}$ The crystal structures were solved by molecular replacement by employing the $5 \mathrm{~L} 6 \mathrm{D}$ structure as the search model in the Phaser program $^{[4]}$ (Phenix package). In the crystals not subjected to soaking, clear electron density for product cofactor S-adenosylL-homocysteine (SAH) is visible. Therefore, in this soaking experiment setup test compounds competed with SAH for the $S$ adenosyl-L-methionine (SAM) binding site. In the crystal structure of UZH1a, the electron density due to the homocysteine part of $\mathrm{SAH}$ was no longer visible. All of the crystallographic models were constructed through iterative cycles of manual model building with $\mathrm{COOT}^{[45]}$ and refinement with phenix.refine. ${ }^{[46]}$ Default XYZ (reciprocal-space), $X Y Z$ (real-space), individual B-factors and occupancies refinement parameters appropriate for the resolution range were utilized. During the first run of the refinement update water was used in phenix.refine followed by addition of the missing water molecules manually.

\section{Selectivity profiling}

For kinase inhibition testing, Merck-Millipore KinaseProfiler ${ }^{\mathrm{TM}}$ assay (radiometric, activity testing) was performed by Eurofins (Luxembourg). UZH1a was tested in single dose mode, in duplicate, at $10 \mu \mathrm{M}$, concentration of ATP was $10 \mu \mathrm{M}$. The required volume of the $50 \times$ stock of UZH1a in DMSO was added to the assay well, before a reaction mix containing an enzyme and substrate was added. The reaction was initiated by the addition of ATP. There was no pre-incubation of the compound with the enzyme/substrate mix prior to ATP addition. For further details of each individual assay, please refer to the company's website.

For protein methyltransferase inhibition testing, HotSpot Methyltransferase Profiling assay was performed by Reaction Biology 
Corporation (Malvern, PA). UZH1a was tested in single dose mode, in duplicate, at $10 \mu \mathrm{M}$. Control compounds, SAH (S-(5'-adenosyl)L-homocysteine) or chaetocin, were tested in 10-dose $\mathrm{IC}_{50}$ mode with 3-fold serial dilution starting at 100 or $200 \mu \mathrm{M}$. Reactions were carried out at $1 \mu \mathrm{M}$ SAM.

\section{Caco-2 cell permeability assay}

The UZH1a intestinal permeability has been evaluated in Caco2 cell permeability assay by ChemPartner (Shanghai, China) following standard procedures. Briefly, Caco-2 monolayer cells were cultured in Millicell-24 ${ }^{\circledR}$ cell culture plates (Merk Millipore; surface area of the membrane $=0.7 \mathrm{~cm}^{2}, \mathrm{~V}_{\mathrm{A}}=0.8 \mathrm{~mL}$ (A-to-B) or $0.4 \mathrm{~mL}$ (Bto-A)). The cell permeability of UZH1a along with the reference compounds (i.e., erythromycin, metoprolol, and atenolol) was tested at $10 \mu \mathrm{M}$ in HBSS buffer containing $0.4 \%$ DMSO (v/v) final concentration. The compounds were placed either in apical or basolateral chamber, and their concentrations were evaluated in both compartments after the 90 -min incubation at $37^{\circ} \mathrm{C}$ using the API $4000^{\mathrm{TM}} \mathrm{LC} / \mathrm{MS} / \mathrm{MS}$ system (Applied Biosystems, Waltham, MA). The Caco-2 monolayer's leakiness after the treatment was evaluated by measuring concentrations of a fluorescent dye Lucifer Yellow with low cell permeability ( $5 \mu \mathrm{M}$ initial concentration) using a fluorometer (at Ex/Em of $485 / 535 \mathrm{~nm}$ ). Lucifer Yellow $\mathrm{P}_{\mathrm{app}}$ values were lower than $1 \cdot 10^{-6} \mathrm{~cm} / \mathrm{s}$, and transepithelial electrical resistance (TEER) values were higher than $400 \Omega \cdot \mathrm{cm}^{2}$, verifying that the Caco-2 monolayers were intact. Mass recovery of UZH1a was $82.4 \%$ (A-to-B) and $92.4 \%$ (B-to-A), indicating low non-specific adsorption to the assay chambers. Compound permeability was evaluated in duplicates.

Compound permeability was calculated according to the following equation, where $V_{A}$ is the volume in the acceptor well, area is the surface area of the membrane and time is the total transport time in seconds:

$$
\mathrm{P}_{a p p}=\frac{V_{A} \times[\text { Compound }]_{\text {acceptor }} \times \text { Dilution Factor }}{\text { Area } \times \text { Time } \times[\text { Compound }]_{\text {donor, initial }}}
$$

Lucifer Yellow permeability was calculated according to the following equation:

$$
\mathrm{P}_{a p p}=\frac{V_{A} \times\left([R F U]_{\text {acceptor }}-[R F U]_{\text {blank }}\right) \times \text { Dilution Factor }}{\text { Area } \times \text { Time } \times\left([R F U]_{\text {donor, initial }}-[R F U]_{\text {blank }}\right)}
$$

Compound recovery was calculated according to the following equation:

$$
\begin{aligned}
& \text { Recovery }(\%)=
\end{aligned}
$$

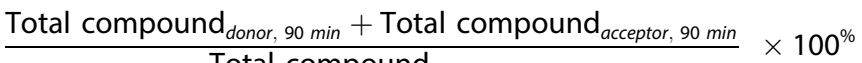

Transepithelial electrical resistance (TEER) was calculated according to the following equation:

$$
\operatorname{TEER}\left(\Omega \cdot \mathrm{cm}^{2}\right)=\left(\text { Resistance }_{\text {sample }}-\text { Resistance }_{\text {blank }}\right) \times \text { Area }
$$

\section{Cell culture}

U2OS and HEK293T cells were maintained in DMEM medium supplemented with $4.5 \mathrm{~g} / \mathrm{L}$ glucose, GlutaMAX ${ }^{\mathrm{TM}}, 10 \% \mathrm{Gibco}^{\mathrm{TM}} \mathrm{FBS}$, and $1 \%$ penicillin/streptomycin (complete medium) in $5 \% \mathrm{CO}_{2}$ at $37^{\circ} \mathrm{C}$ in a humidified incubator, with regular passaging twice a week using 1:5 split ratio. MOLM-13 cells were cultured in RPMI 1640 medium containing $10 \%$ Gibco $^{\mathrm{TM}} \mathrm{FBS}$ and $1 \%$ penicillin/ streptomycin (complete medium) in $5 \% \mathrm{CO}_{2}$ at $37^{\circ} \mathrm{C}$ in a humidified incubator, with maintained cell densities at 0.6$2 \cdot 10^{6}$ cells $/ \mathrm{mL}$. All cell lines have been authenticated by cell line typing (external service provided by Microsynth, Switzerland). All cell lines were tested negative for mycoplasma contamination (PCR-based assay by Microsynth, Switzerland).

\section{Cellular target engagement assay InCELL Pulse}

Gene encoding METTL3 catalytic domain (residue 356-580) was amplified using primers listed below:

\section{pICP-N-M3-F: ATATGAATTCACACAGAGTGTCGGAGGTGATTCC}

\section{pICP-N-M3-R: ATGCTCTAGATTATAAATTCTTAGGTTTAGAGATGATAC- CATCTGGG}

\section{The amplified gene was ligated into the pICP-ePL-N vector between EcoRI and Xbal restriction sites}

Cellular target engagement of the compounds was evaluated using InCELL Pulse assay according to the manufacturer's instructions. Briefly, HEK293T cells were seeded at $1 \cdot 10^{6}$ cells/well in $2 \mathrm{~mL}$ complete medium in a 6-well plate and transfected with $1.5 \mu \mathrm{g}$ of the plasmid encoding enhanced ProLabel ${ }^{\circledast}$ (ePL) enzyme fragment (42 aa) fused to the N-terminus of the METTL3 catalytic domain (residues 354-580) using Lipofectamine RNAiMAX for $24 \mathrm{~h}$. After the transfection, cells were washed once with Opti-MEM medium, detached from the plate by gentle washing and counted. Forty microliters of Opti-MEM medium containing 5000 transfected cells were mixed with $10 \mu \mathrm{L}$ of $5 \times$ compound (UZH1a or UZH1b) solution in Opti-MEM or $2.5 \%(\mathrm{v} / \mathrm{v})$ of DMSO $(5 \times)$ as a negative control and incubated for $1 \mathrm{~h}$ at $37^{\circ} \mathrm{C}$. After the incubation, cells were heated at $46^{\circ} \mathrm{C}$ for $3 \mathrm{~min}$ followed by incubation at $22^{\circ} \mathrm{C}$ for $3 \mathrm{~min}$, and the non-aggregated METTL3-ePL protein was quantified using luminescence-based assay according to the InCELL Pulse kit's instructions.

\section{Quantification of $\mathrm{m}^{6} \mathrm{~A} / \mathrm{A}$ ratio in polyadenylated RNA and total RNA by UPLC-MS/MS analysis}

MOLM-13 cells were seeded into 6 well plates at a density of $1.10^{6}$ cells $/ \mathrm{mL}$ in $2 \mathrm{~mL}$ of complete RPMI medium. U2OS cells were seeded at $5 \cdot 10^{5}$ cells/well in a 6 -well plate, whereas HEK293T cells were seeded at $1 \cdot 10^{6}$ cells/well. After $24 \mathrm{~h}$, cells were treated with increasing concentrations of UZH1a or UZH1b in DMSO or DMSO alone as a negative control (final concentration of DMSO $0.5 \%$ (v/ v)) for indicated time points. For the long-term incubation studies, U2OS cells were seeded at $1.5 \cdot 10^{5}$ cells/well in a 6-well plate. After $24 \mathrm{~h}$, cells were treated with $40 \mu \mathrm{M}$ of UZH1a in DMSO or DMSO alone as a negative control (final concentration of DMSO $0.5 \%$ (v/ v)) for 3 days or, after reseeding at $1.5 \cdot 10^{5}$ cells/well and adding fresh compound, 6 days in total. Following incubation in cell culture incubator, cells were washed once with PBS, and total RNA was extracted using $0.5 \mathrm{~mL}$ of GENEzol ${ }^{\mathrm{TM}}$ reagent according to manufacturer's instructions. The final volume of $50 \mu \mathrm{L}$ of total RNA eluate was subjected to two rounds of purification using $25 \mu \mathrm{L}$ Sera-Mag magnetic oligo(dT) particles per sample. The polyadenylated RNA was eluted with nuclease-free water in a final volume of $25 \mu \mathrm{L}$, and its concentration was determined using NanoDrop. One hundred nanograms of mRNA was digested to nucleosides and dephosphorylated in a one-pot reaction using $0.5 \mu \mathrm{L}$ of nucleoside digestion mix in $25 \mu \mathrm{L}$ of total reaction volume for 4 hours at $37^{\circ} \mathrm{C}$. 
The samples were used for UPLC-MS/MS analysis without further purification steps.

Nucleoside UPLC-MS/MS was performed at the Functional Genomics Centre Zurich following previously described procedures with slight modifications. ${ }^{[47][48]}$ Briefly, the samples were diluted 10 or 100 -fold in solvent $A(0.1 \%(\mathrm{v} / \mathrm{v})$ formic acid in water), separated using a Waters Aquity M class (Waters) UPLC and detected with a TSQ Quantiva (Thermo Scientific) mass spectrometer by using a nano electrospray ionization (ESI) source in SRM mode. Analytes were separated on an HSS T3 column (particle size $1.8 \mu \mathrm{m}$, dimensions $0.15 \times 60 \mathrm{~mm}$ ). The mobile phases used for elution were A $0.1 \%(\mathrm{v} / \mathrm{v})$ formic acid in water and B $0.1 \%(\mathrm{v} / \mathrm{v})$ formic acid in acetonitrile at a flow rate of $2 \mu \mathrm{L} / \mathrm{min}$, column temperature was ambient, sample temperature was $8^{\circ} \mathrm{C}$, injection volume was set to $1 \mu \mathrm{L}$, and sample loop volume was $1 \mu \mathrm{L}$. The analytes were separated following a gradient of $0-4 \mathrm{~min} 12.5 \% \mathrm{~B}, 4-4.1 \mathrm{~min} 99 \%$ $\mathrm{B}, 4.1-4.6 \mathrm{~min} 12.5 \% \mathrm{~B}, 6 \mathrm{~min} 12.5 \% \mathrm{~B}$. Adenosine, $\mathrm{m}^{6} \mathrm{~A}, \mathrm{~m}^{1} \mathrm{~A}$, and $\mathrm{m}^{6} \mathrm{~A}_{\mathrm{m}}$ eluted at $3.30 \mathrm{~min}, 3.44 \mathrm{~min}, 2.89 \mathrm{~min}$, and $3.56 \mathrm{~min}$, respectively. Guanosine and $\mathrm{m}^{7} \mathrm{G}$ eluted at $3.34 \mathrm{~min}$ and $3.27 \mathrm{~min}$, respectively. The mass spectrometer was operated using the following parameters: ESI positive ion mode, SRM acquisition mode, capillary voltage $3 \mathrm{kV}$, source temperature $300^{\circ} \mathrm{C}$, collision energy of $15 \mathrm{~V}$ for adenosine and guanosine, $20 \mathrm{~V}$ for $\mathrm{m}^{7} \mathrm{G}$, and $25 \mathrm{~V}$ for $\mathrm{m}^{6} \mathrm{~A}, \mathrm{~m}^{1} \mathrm{~A}$, and $\mathrm{m}^{6} \mathrm{~A} m$. Adenosine, $\mathrm{m}^{6} \mathrm{~A}, \mathrm{~m}^{1} \mathrm{~A}$, and $\mathrm{m}^{6} \mathrm{~A}_{\mathrm{m}}$ were detected by monitoring precursor to product transitions of $\mathrm{m} / \mathrm{z}=268.1 \rightarrow 136.1, \mathrm{~m} / \mathrm{z}=282.1 \rightarrow 150.1, \mathrm{~m} / \mathrm{z}=282.1 \rightarrow 150.1$, and $\mathrm{m} / \mathrm{z}=296.1 \rightarrow 152.1$, respectively. Guanosine and $\mathrm{m}^{7} \mathrm{G}$ were detected by monitoring precursor to product transitions of $\mathrm{m} / \mathrm{z}=284.1 \rightarrow 136.1$ and $\mathrm{m} / \mathrm{z}=298.1 \rightarrow 166.1$, respectively. Absolute concentrations of adenosine, guanosine, $m^{6} A, m^{1} A, m^{6} A_{m}$ and $m^{7} G$ in the samples were determined based on an external calibration curve generated using adenosine (Sigma-Aldrich, 01890-5G), guanosine (Sigma-Aldrich, G6264-1G), $\mathrm{m}^{6} \mathrm{~A}$ (Chemie Brunschwig, CBLQB-1055-1 g), m ${ }^{1} A$ (MedChem Express, MCE-HY-113081), $m^{6} A_{m}$ (Toronto Research Chemicals, D447415), and $\mathrm{m}^{7} \mathrm{G}$ (Sigma-Aldrich, M0627-100MG) nucleoside standards. The modified-to-nonmodified nucleoside ratio of compound-treated samples were normalized to the corresponding value of DMSO-treated negative control. All measurements were performed in technical duplicates and repeated in at least three biological replicates on different days. Inhibition curves were plotted in GraphPad Prism 8.4 and fitted with nonlinear regression "log(inhibitor) vs. normalized responsevariable slope" with the maximal inhibition fixed at $80 \%$, from which $\mathrm{IC}_{50}$ values were determined.

\section{RNAi-mediated knockdown of METTL3}

For western blotting experiments, HEK293T or U2OS cells were seeded in 6-well plates at a density of $1.5 \cdot 10^{5}$ cells/well in $2 \mathrm{~mL}$ of complete DMEM medium, transfected with total $50 \mathrm{nM}$ of METTL3targeting siRNA mix (at equimolar ratio) or negative control siRNA using Lipofectamine ${ }^{\circledast}$ RNAiMAX according to manufacturer's instructions, and incubated at $37^{\circ} \mathrm{C}$ with $5 \% \mathrm{CO}_{2}$. The sequences of siRNAs are provided in the materials section. After $72 \mathrm{~h}$, cells were analyzed for METTL3 protein expression using western blotting as described in the western blotting section.

To evaluate the effect of METTL3 knockdown on $\mathrm{m}^{6} \mathrm{~A} / \mathrm{A}$ level in polyadenylated RNA, HEK293T or U2OS cells were seeded in 6-well plates and transfected as described above. After $72 \mathrm{~h}, \mathrm{~m}^{6} \mathrm{~A} / \mathrm{A}$ ratio reduction in polyadenylated RNA was evaluated as described in UPLC-MS/MS analysis section. The assay was repeated three times on different days.

\section{Western blotting}

For immunodetection of METTL3 expression level after the compound exposure, MOLM-13 cells were seeded at $1 \cdot 10^{6}$ cells $/ \mathrm{mL}$ in a 6-well plate in complete RPMI media. The next day, cells were treated with the indicated doses of compounds. After 16 hours of treatment, cells were collected by centrifugation, washed once with PBS, and resuspended in $200 \mu \mathrm{L}$ of RIPA buffer $(150 \mathrm{mM}$ sodium chloride, $1 \%(\mathrm{v} / \mathrm{v})$ IGAPAL CA630, $0.5 \%(\mathrm{w} / \mathrm{v})$ sodium deoxycholate, $0.1 \%(\mathrm{v} / \mathrm{v})$ sodium dodecyl sulphate, $50 \mathrm{mM}$ Tris-HCl) with added protease inhibitor cocktail ( $1 \times$ final concentration). After incubating for 30 minutes on ice, cell lysates were centrifuged for 1520 minutes at $16000 \times \mathrm{g}$ at $4{ }^{\circ} \mathrm{C}$ to remove cell debris, and the supernatant containing proteins was collected. The protein concentration was quantified with Pierce ${ }^{\mathrm{TM}}$ Coomassie (Bradford) protein assay kit, and $30 \mu \mathrm{g}$ of protein was loaded per well on a SurePAGE $12 \%$ Bis-Tris polyacrylamide gel. Following electrophoresis, the proteins were transferred to methanol-activated low fluorescence PVDF membrane using Trans-Blot ${ }^{\circledR}$ Turbo $^{\mathrm{TM}}$ Transfer System (BioRad, Hercules, CA) according to manufacturer's instructions. The membrane was then blocked with $5 \%$ non-fat milk and incubated with anti-METTL3 rabbit $(1: 1000)$ and anti- $\beta$-actin mouse $(1: 5000)$ antibodies overnight at $4{ }^{\circ} \mathrm{C}$. The next day, the membrane was washed 3 times with PBST (PBS with $0.1 \%(\mathrm{v} / \mathrm{v})$ Tween-20) and incubated with IRDye ${ }^{\circledR} 800 \mathrm{CW}$ goat anti-rabbit IgG and IRDye ${ }^{\oplus}$ 680RD donkey anti-mouse IgG secondary antibodies $(1: 10000)$ for 2 hours at room temperature. After incubation, the membrane was again washed three times in PBST, and fluorescence signal was detected on Odyssey ${ }^{\oplus}$ CLx Imaging System (LI-COR). The band intensity in each lane was quantified using Image Studio Lite Version 5.2.5 (LI-COR). For the detection of METTL3 protein in U2OS and HEK293T cells following the siRNA-mediated knockdown, the cells were washed with PBS and lysed in $60 \mu \mathrm{L}$ of lysis buffer. Cell lysates were probed for METTL3 expression as described above.

\section{Statistical analysis}

The statistical analysis was performed using GraphPad Prism software. Multiple experimental groups were compared pairwise using the one-way analysis of variance (ANOVA) followed by Tukey's post-hoc test unless stated otherwise, normality was assessed using Shapiro-Wilk test. The differences between treatment groups were considered statistically significant at $p$-values lower than 0.05 .

\section{Acknowledgements}

The authors thank Yuanding Chen (Shanghai Medicilon Inc.) for the synthesis of the UZH1a and UZH1b compounds and Eleen Laul for her help with chemical characterization of the compounds. The authors are grateful to Beat Blattmann for his help with setting up protein crystallization trials. We thank the staff at the Swiss Light Source (Paul Scherrer Institute) for their support with data collection. We thank the Swiss National Supercomputing Centre (CSCS) in Lugano for providing the computational resources. We also thank Dr. Endre Laczko and Dr. Stefan Schauer from Functional Genomics Center Zurich for their help with UPLCMS/MS analysis. We thank Dr. Paweł Śledź, Dr. Katherine Rollins, Prof. Dr. Marianne Hürzeler, and Dr. Claude Schärer for interesting discussions. We also thank Dr. Katherine Rollins for reading the manuscript and very useful suggestions for improving its clarity. This work was supported financially by the Swiss National Science 
Foundation (E.M.-O., grant CRSK-3_190825; A.C., Excellence grant 310030B-189363) and the Swiss Cancer Research foundation (E.M.-O., A.C., grant KFS-5016-02-2020).

\section{Conflict of Interest}

The authors declare no conflict of interest.

\section{Keywords: METTL3 - RNA methyltransferase inhibitor} epitranscriptomics $\cdot \mathrm{m} 6 \mathrm{~A} \cdot$ leukemia

[1] L. P. Vu, Y. Cheng, M. G. Kharas, Cancer Dis. 2019, 9, 25-33.

[2] R. V. Kadumuri, S. C. Janga, Trends Mol. Med. 2018, 24, 886-903.

[3] Y. Fu, D. Dominissini, G. Rechavi, C. He, Nat. Rev. Genet. 2014, 15, 293 306.

[4] S. Ke, A. Pandya-Jones, Y. Saito, J. J. Fak, C. B. Vågbø, S. Geula, J. H. Hanna, D. L. Black, J. E. Darnell, R. B. Darnell, Genes Dev. 2017, 31, 990 1006.

[5] D. P. Patil, C.-K. Chen, B. F. Pickering, A. Chow, C. Jackson, M. Guttman, S. R. Jaffrey, Nature 2016, 537, 369-373.

[6] B. S. Zhao, I. A. Roundtree, C. He, Nat. Rev. Mol. Cell Biol. 2017, 18, 31-42.

[7] K. E. Pendleton, B. Chen, K. Liu, O. V. Hunter, Y. Xie, B. P. Tu, N. K. Conrad, Cell 2017, 169, 824-835.e14.

[8] Z. lanniello, A. Paiardini, A. Fatica, Front. Oncol. 2019, 9, 1-11.

[9] I. Barbieri, K. Tzelepis, L. Pandolfini, J. Shi, G. Millán-Zambrano, S. C. Robson, D. Aspris, V. Migliori, A. J. Bannister, N. Han, E. De Braekeleer, H. Ponstingl, A. Hendrick, C. R. Vakoc, G. S. Vassiliou, T. Kouzarides, Nature 2017, 552, 126-131.

[10] L. P. Vu, B. F. Pickering, Y. Cheng, S. Zaccara, D. Nguyen, G. Minuesa, T. Chou, A. Chow, Y. Saletore, M. MacKay, J. Schulman, C. Famulare, M. Patel, V. M. Klimek, F. E. Garrett-Bakelman, A. Melnick, M. Carroll, C. E. Mason, S. R. Jaffrey, M. G. Kharas, Nat. Med. 2017, 23, 1369-1376.

[11] W. Zhang, X. He, J. Hu, P. Yang, C. Liu, J. Wang, R. An, J. Zhen, M. Pang, K. Hu, X. Ke, X. Zhang, H. Jing, Oncol. Lett. 2019, 18, 3682-3690.

[12] S. R. Kumar, K. H. Taylor, J. N. Bryan, A. M. Eaton, Rna Dis. 2017, 2-7.

[13] M. Cheng, L. Sheng, Q. Gao, Q. Xiong, H. Zhang, M. Wu, Y. Liang, F. Zhu, Y. Zhang, X. Zhang, Q. Yuan, Y. Li, Oncogene 2019, 38, 3667-3680.

[14] J. Han, J. Z. Wang, X. Yang, H. Yu, R. Zhou, H. C. Lu, W. B. Yuan, J. C. Lu, Z. J. Zhou, Q. Lu, J. F. Wei, H. Yang, Mol. Cancer 2019, 18, 1-15.

[15] W. Wei, B. Huo, X. Shi, Cancer Manag. Res. 2019, 11, 1177-1187.

[16] J. Choe, S. Lin, W. Zhang, Q. Liu, L. Wang, J. Ramirez-Moya, P. Du, W. Kim, S. Tang, P. Sliz, P. Santisteban, R. E. George, W. G. Richards, K.-K. Wong, N. Locker, F. J. Slack, R. I. Gregory, Nature 2018, 561, 556-560.

[17] W. Hua, Y. Zhao, X. Jin, D. Yu, J. He, D. Xie, P. Duan, Gynecol. Oncol. 2018, 151, 356-365.

[18] W. Miao, J. Chen, L. Jia, J. Ma, D. Song, Biochem. Biophys. Res. Commun. 2019, 516, 719-725.

[19] T. Li, P. S. Hu, Z. Zuo, J. F. Lin, X. Li, Q. N. Wu, Z. H. Chen, Z. L. Zeng, F. Wang, J. Zheng, D. Chen, B. Li, T. B. Kang, D. Xie, D. Lin, H. Q. Ju, R. H. $\mathrm{Xu}$, Mol. Cancer 2019, 18, 1-15.

[20] M. Chen, L. Wei, C. T. Law, F. H. C. Tsang, J. Shen, C. L. H. Cheng, L. H. Tsang, D. W. H. Ho, D. K. C. Chiu, J. M. F. Lee, C. C. L. Wong, I. O. L. Ng C. M. Wong, Hepatology 2018, 67, 2254-2270.

[21] Q. Wang, C. Chen, Q. Ding, Y. Zhao, Z. Wang, J. Chen, Z. Jiang, Y. Zhang, G. Xu, J. Zhang, J. Zhou, B. Sun, X. Zou, S. Wang, Gut 2020, 69, 11931205.

[22] D. Dominissini, S. Moshitch-Moshkovitz, S. Schwartz, M. Salmon-Divon, L. Ungar, S. Osenberg, K. Cesarkas, J. Jacob-Hirsch, N. Amariglio, M. Kupiec, R. Sorek, G. Rechavi, Nature 2012, 485, 201-206.

[23] P. Knuckles, T. Lence, I. U. Haussmann, D. Jacob, N. Kreim, S. H. Carl, I. Masiello, T. Hares, R. Villaseñor, D. Hess, M. A. Andrade-Navarro, M. Biggiogera, M. Helm, M. Soller, M. Bühler, J.-Y. Roignant, Genes Dev. 2018, 32, 415-429.

[24] X. Wang, J. Feng, Y. Xue, Z. Guan, D. Zhang, Z. Liu, Z. Gong, Q. Wang, J. Huang, C. Tang, T. Zou, P. Yin, Nature 2016, 534, 575-578.
[25] P. Śledź, M. Jinek, eLife 2016, 5, 1-16.

[26] P. Wang, K. A. Doxtader, Y. Nam, Mol. Cell 2016, 63, 306-317.

[27] S. Oerum, M. Catala, C. Atdjian, F. Brachet, L. Ponchon, P. Barraud, L. lannazzo, L. Droogmans, E. Braud, M. Ethève-Quelquejeu, C. Tisné, RNA Biol. 2019, 16, 798-808.

[28] F. Ye, W. Zhang, W. Lu, Y. Xie, H. Jiang, J. Jin, C. Luo, BioMed Res. Int. 2016, 2016, 1-8.

[29] R. K. Bedi, D. Huang, S. A. Eberle, L. Wiedmer, P. Śledź, A. Caflisch, ChemMedChem 2020, 15, 744-748.

[30] L. Wiedmer, S. A. Eberle, R. K. Bedi, P. Śledź, A. Caflisch, Anal. Chem. 2019, 91, 3078-3084.

[31] E. Yang, E. van Nimwegen, M. Zavolan, N. Rajewsky, M. Schroeder, M. Magnasco, J. E. Darnell, Genome Res. 2003, 13, 1863-1872.

[32] X. Wang, Z. Lu, A. Gomez, G. C. Hon, Y. Yue, D. Han, Y. Fu, M. Parisien, Q. Dai, G. Jia, B. Ren, T. Pan, C. He, Nature 2014, 505, DOI 10.1038/ nature12730.

[33] H. Du, Y. Zhao, J. He, Y. Zhang, H. Xi, M. Liu, J. Ma, L. Wu, Nat. Commun. 2016, 7, DOI 10.1038/ncomms12626.

[34] S. Schwartz, M. R. Mumbach, M. Jovanovic, T. Wang, K. Maciag, G. G. Bushkin, P. Mertins, D. Ter-Ovanesyan, N. Habib, D. Cacchiarelli, N. E. Sanjana, E. Freinkman, M. E. Pacold, R. Satija, T. S. Mikkelsen, N. Hacohen, F. Zhang, S. A. Carr, E. S. Lander, A. Regev, Cell Rep. 2014, 8, 284-296.

[35] N. van Tran, F. G. M. Ernst, B. R. Hawley, C. Zorbas, N. Ulryck, P. Hackert, K. E. Bohnsack, M. T. Bohnsack, S. R. Jaffrey, M. Graille, D. L. J. Lafontaine, Nucleic Acids Res. 2019, 47, 7719-7733.

[36] R. Pinto, C. B. Vågbø, M. E. Jakobsson, Y. Kim, M. P. Baltissen, M.-F. O'Donohue, U. H. Guzmán, J. M. Małecki, J. Wu, F. Kirpekar, J. V. Olsen, P.-E. Gleizes, M. Vermeulen, S. A. Leidel, G. Slupphaug, P. Ø. Falnes, Nucleic Acids Res. 2019, 48, 830-846.

[37] P. Boccaletto, M. A. MacHnicka, E. Purta, P. Pitkowski, B. Baginski, T. K. Wirecki, V. De Crécy-Lagard, R. Ross, P. A. Limbach, A. Kotter, M. Helm, J. M. Bujnicki, Nucleic Acids Res. 2018, 46, D303-D307.

[38] H. T. Abelson, L. F. Johnson, S. Penman, H. Green, Cell 1974, 1, 161-165.

[39] A. Alexandrov, M. R. Martzen, E. M. Phizicky, RNA 2002, 8, 1253-1266.

[40] R. A. Cartlidge, A. Knebel, M. Peggie, A. Alexandrov, E. M. Phizicky, P. Cohen, EMBO J. 2005, 24, 1696-1705.

[41] L.-S. Zhang, C. Liu, H. Ma, Q. Dai, H.-L. Sun, G. Luo, Z. Zhang, L. Zhang, L. Hu, X. Dong, C. He, Mol. Cell 2019, 74, 1304-1316.e8.

[42] L. Pandolfini, I. Barbieri, A. J. Bannister, A. Hendrick, B. Andrews, N. Webster, P. Murat, P. Mach, R. Brandi, S. C. Robson, V. Migliori, A Alendar, M. D'Onofrio, S. Balasubramanian, T. Kouzarides, Mol. Cell 2019, 74, 1278-1290.e9.

[43] P. Filippakopoulos, J. Qi, S. Picaud, Y. Shen, W. B. Smith, O. Fedorov, E. M. Morse, T. Keates, T. T. Hickman, I. Felletar, M. Philpott, S. Munro, M. R. McKeown, Y. Wang, A. L. Christie, N. West, M. J. Cameron, B. Schwartz, T. D. Heightman, N. La Thangue, C. A. French, O. Wiest, A. L. Kung, S. Knapp, J. E. Bradner, Nature 2010, 468, 1067-1073.

[44] A. J. McCoy, R. W. Grosse-Kunstleve, P. D. Adams, M. D. Winn, L. C. Storoni, R. J. Read, J. Appl. Crystallogr. 2007, 40, 658-674.

[45] P. Emsley, B. Lohkamp, W. G. Scott, K. Cowtan, Acta Crystallogr. Sect. D 2010, 66, 486-501.

[46] P. V. Afonine, R. W. Grosse-Kunstleve, N. Echols, J. J. Headd, N. W. Moriarty, M. Mustyakimov, T. C. Terwilliger, A. Urzhumtsev, P. H. Zwart, P. D. Adams, Acta Crystallogr. Sect. D 2012, 68, 352-367.

[47] M. A. Garcia-Campos, S. Edelheit, U. Toth, M. Safra, R. Shachar, S. Viukov, R. Winkler, R. Nir, L. Lasman, A. Brandis, J. H. Hanna, W. Rossmanith, S. Schwartz, Cell 2019, 178, 731-747.e16.

[48] Y. Huang, R. Su, Y. Sheng, L. Dong, Z. Dong, H. Xu, T. Ni, Z. S. Zhang, T. Zhang, C. Li, L. Han, Z. Zhu, F. Lian, J. Wei, Q. Deng, Y. Wang, M. Wunderlich, Z. Gao, G. Pan, D. Zhong, H. Zhou, N. Zhang, J. Gan, H. Jiang, J. C. Mulloy, Z. Qian, J. Chen, C.-G. Yang, Cancer Cell 2019, 35, 677-691.e10

Manuscript received: April 27, 2021

Revised manuscript received: June 29, 2021

Accepted manuscript online: July 8,2021

Version of record online: July 29, 2021 